\title{
Adoption of Knowledge Management System: A Study on How IGracias Should be Adopted for Telkom Campus
}

\author{
Dewi Rahmawati, Noerma Pudji Istyanto, Muhammad Nasrullah \\ Institut Teknologi Telkom Surabaya \\ dewirahmawati@ittelkom-sby.ac.id, noerma@ittelkom-sby.ac.id, emnasrul@ittelkom-sby.ac.id
}

\begin{abstract}
IGraciass is an integrated academic and non-academic management information system from the Telkom Education Foundation (YPT). Based on the vision and mission, the strategy and tagline of the Telkom Education Foundation is "The Leader of ICT Education Provider" and the spirit of digital transformation for Indonesia, I-Graciass must be adopted and implemented in all higher education institutions (lemdikti) under the auspices. The YPT. However, the facts on the ground the adoption and implementation process of IGraciass in each of these higher education institutions are not easy matters. Many features, ease of use of technology and the system interface needed to access the system are important factors in the success of the system. For this reason, this research was conducted with the aim of facilitating the adoption process of IGraciass in all higher education institutions of the Telkom Education Foundation (YPT) according to the respective needs of the educational institutions under the auspices of YPT. This research was carried out using the mixing method both qualitatively and quantitatively, then the researcher also developed a qualitative research instrument to conduct a survey of the users to determine which channels were effective in the process of transferring knowledge. The results show that to minimize the risk of failure in adopting a knowledge management system, companies need to select a system based on the functional, non-functional and transition requirements for the system, as well as the strength and capacity of the organization.
\end{abstract}

Keywords: I-Graciass, Knowledge Management System.

\begin{abstract}
Abstrak
IGraciass merupakan sistem informasi manajemen akademik dan nonakademik terintegrasi dari Yayasan Pendidikan Telkom (YPT). Berdasarkan visi dan misi, strategi dan tagline dari Yayasan Pendidikan Telkom adalah "The Leader of ICT Education Provider" serta semangat transformasi digital untuk Indonesia, maka IGraciass wajib di adopsi dan diimplementasikan di seluruh lembaga pendidikan tinggi (lemdikti) yang ada di bawah nauangan YPT tersebut. Namun, fakta di lapangan proses adopsi dan implementasi I-Graciass di masing-masing lembaga pendidikan tinggi tersebut bukan perihal yang mudah. Fitur yang banyak, kemudahan menggunakan teknologi serta Sistem Interface yang diperlukan untuk mengakses sistem merupakan faktor penting dalam keberhasilan sistem. Untuk itu, penelitian ini dilakukan dengan tujuan agar memudahkan proses adopsi IGraciass di seluruh lembaga pendidikan tinggi Yayasan Pendidikan Telkom (YPT) sesuai dengan kebutuhan masing-masing dari lembaga pendidikan dibawah naungan YPT. Penelitian ini dilaksanakan dengan menggunakan metode mixing method baik secara kualitatif dan kuantitatif, kemudian peneliti juga menyusun instrumen penelitian kualitatif untuk melakukan survey terhadap pihak pengguna untuk mengetahui saluran (channel) yang efektif dalam melakukan proses transfer knowledge. Hasil penelitian menunjukkan bahwa untuk meminimalkan risiko kegagalan dalam mengadopsi sistem knowledge management system, perusahaan perlu memilih sistem berdasarkan persyaratan fungsional, nonfungsional dan transisi untuk sistem, serta kekuatan dan kapasitas organisasi.
\end{abstract}

Kata Kunci: I-Graciass; Knowledge Management System. 


\section{PENDAHULUAN}

Page : 218-227

Knowledge Management System (KMS) adalah proses menciptakan, membagikan, menggunakan, dan mengelola suatu pengetahuan dan informasi dari sebuah organisasi [1] [4] [5] [6] [7]. KMS memiliki siklus sederhana yang dapat dilihat pada Gambar 1. Tahap pertama, yaitu capturing, dapat meliputi salah satu atau beberapa di antara hal-hal berikut ini: pemasukan data, pemindaian, wawancara, serta brainstorming. Tahap organizing dapat meliputi salah satu atau beberapa di antara hal-hal berikut ini: pembuatan katalog, pengindeksan, penyaringan, penghubungan, dan pengkodean. Tahap refining dapat meliputi salah satu atau beberapa di antara hal-hal berikut ini: kontekstualisasi, kerjasama, kompresi, serta pembuatan proyeksi. Tahap transfer dapat meliputi salah satu atau beberapa di antara hal-hal berikut ini: pembagian dan peringatan. Gambar 1 adalah gambar piramida kognitif manajemen pengetahuan. Ruang lingkup dan hasil penelitian pada penelitian ini adalah berfokus pada peneliti lebih ke arah identifikasi dan analisa KMS di Yayasan Pendidikan Telkom (YPT) dalam hal ini terkait adopsi dan implementasi I-Graciass ke seluruh lemdikti dengan studi kasus yang ada di ITTelkom Surabaya serta Rekomendasi model KMS yang efektif untuk digunakan oleh YPT guna membantu mempermudah proses adopsi dan implementasi bagi seluruh lemdikti termasuk ITTelkom Surabaya.

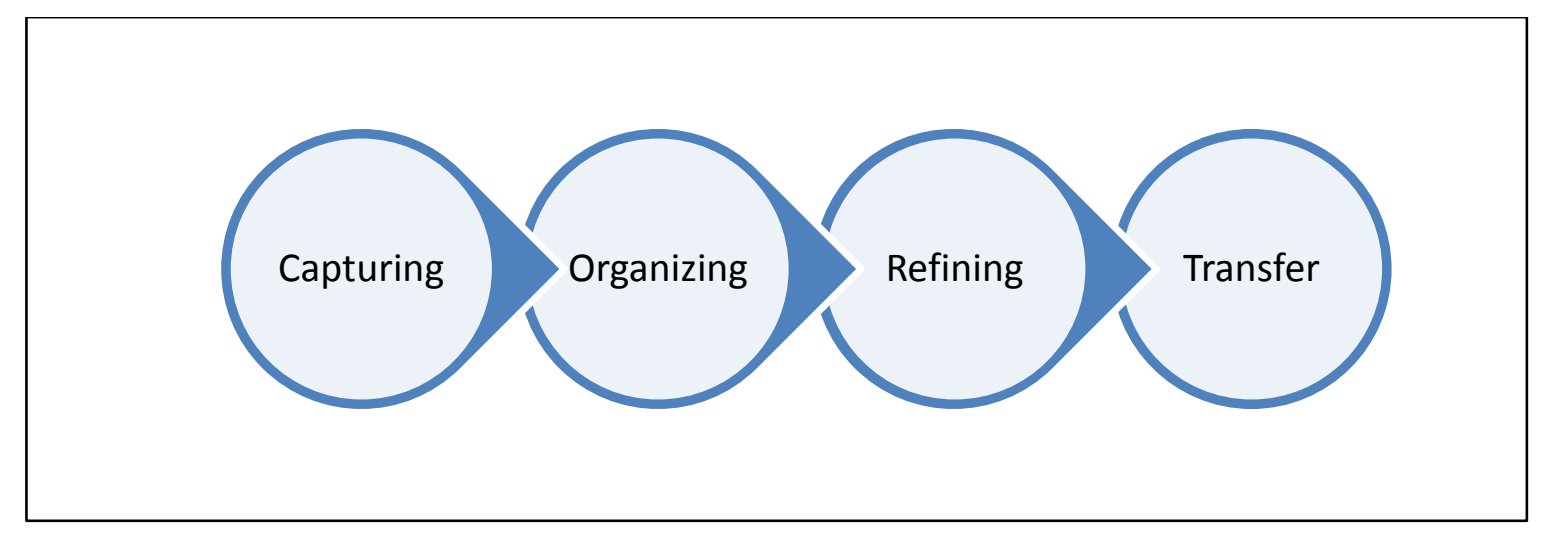

Gambar 1. Siklus Hidup Sederhana Knowledge Management System (KMS)

KMS memiliki konsep Piramida Kognitif Manajemen Pengetahuan [2] [3]. Piramida kognitif manajemen pengetahuan terdiri dari empat elemen, yang pertama adalah Data. Data adalah elemen yang paling dasar, bersifat diskrit, dan belum diproses, sehingga belum memiliki makna. Contoh: angka, kata, kode, tabel, dan basis data [8] [12]. Kemudian terdapat Informasi adalah elemen yang saling terhubung dan merupakan hasil pemrosesan terhadap data, sehingga memiliki suatu makna [9]. Contoh: kalimat, paragraf, persamaan, konsep, ide, pertanyaan, dan cerita sederhana. Yang ketiga yakni Pengetahuan adalah kumpulan informasi yang terorganisir mengenai suatu bidang yang sudah dipahami [10]. Contoh: teori, aksiom, kerangka kerja konseptual, cerita rumit, dan fakta. Dan terakhir adalah Kebijaksanaan adalah hasil penerapan dari suatu pengetahuan yang dapat menjadi dasar dalam pengambilan keputusan [11]. Contoh: buku, paradigma, sistem, filosofi, puisi, sistem kepercayaan, tradisi, prinsip, dan kebenaran. 
Gambar 2. Kuisioner Tingkat Kepuasan Mahasiswa terhadap Layanan IGracias

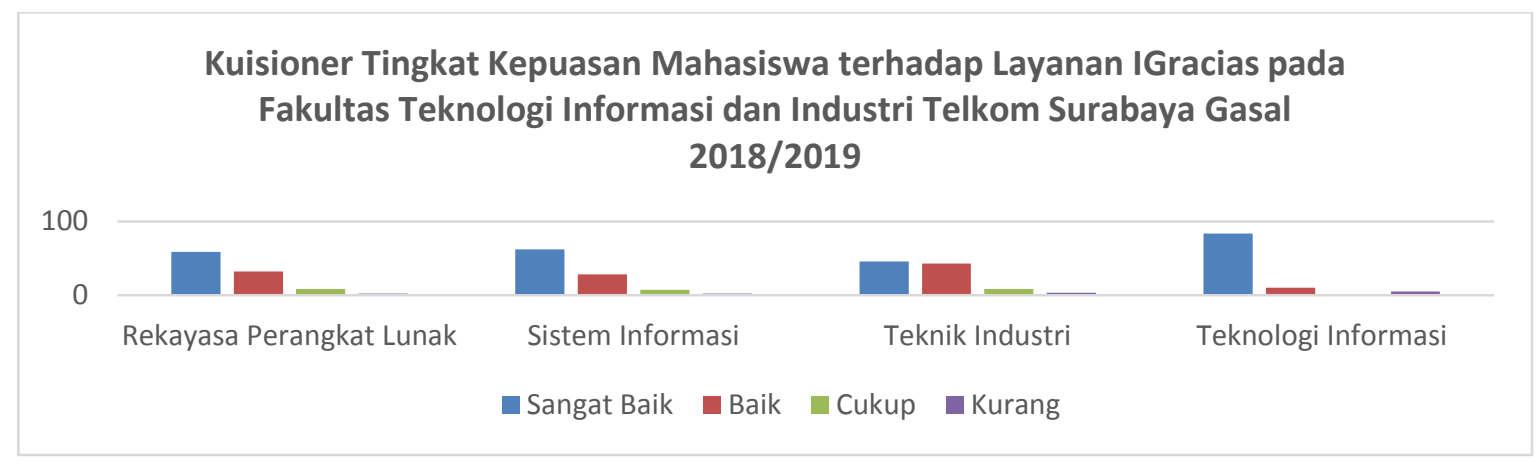

Data kepuasan mahasiswa terhadap kecukupan, aksesibitas, kualitas sarana dan prasarana, dan layanan IGracias dapat dilihat pada Gambar 2. Pada kuisioner tersebut menunjukkan bahwa terdapat mahasiswa yang masih merasa kurang terhadap kepuasan layanan IGracias. Sekitar 2-5\% mahasiswa masih merasa kurang puas terhadap layanan IGracias. Untuk itu, penelitian ini dilakukan dengan maksud menganalisa manakah yang menjadi faktor kesuksesan atau penghambat dari suatu sistem IGracias yang sedang dijalankan.

Dari data kepuasan tersebut, untuk itu kita memerlukan sistem adopsi layanan IGracias yang baik dan tepat. Hal ini dapat dimulai dengan mengetahui sistem konsep Pengetahuan KMS. Secara umum, pengetahuan dapat digolongkan ke dalam 2 kategori, yakni Tacit (know-how) dan Explicit (know-what). Pengetahuan tacit adalah pengetahuan yang masih berupa pemikiran di kepala manusia. Pengetahuan ini agak sulit untuk dikomunikasikan, dipahami dan diterjemahkan ke dalam bentuk lain yang lebih terstruktur karena bersumberkan pada pengalaman atau intuisi pribadi serta bergantung pada konteks. Sedangkan Pengetahuan explicit adalah pengetahuan yang sudah direpresentasikan dalam media tertentu. Pengetahuan ini mudah untuk dikomunikasikan, dipahami, dan diterjemahkan ke dalam bentuk lain yang lebih terstruktur, sehingga dapat dikelola oleh Knowledge Management System (KMS). [2] [3]

Ikujiro Nonaka dan Hirakata Takeuchi (1995) beranggapan bahwa pengetahuan merupakan suatu hal yang dinamis dan dapat berubah bentuk dari tacit menjadi explicit ataupun sebaliknya. Mereka kemudian mengusulkan suatu model proses penciptaan pengetahuan yang memungkinkan organisasi untuk mengelola proses tersebut secara efektif. Model yang mereka usulkan ini disebut dengan model dimensi pengetahuan SECI. Hal ini bisa dilihat pada Gambar 2.

\section{Tinjauan Pustaka}

Mengacu pada [4], dalam KMS, Faktor manusia didefinisikan sebagai pengetahuan tentang kemampuan manusia dan keterbatasan pada desain sistem, organisasi, pekerjaan, mesin, peralatan, dan produk konsumen untuk penggunaan yang aman, efisien, dan nyaman. Makalah ini telah menyajikan studi penelitian yang sedang berlangsung yang menyelidiki faktor-faktor yang memastikan efektivitas Sistem Manajemen pengetahuan. Model faktor-faktor yang berkontribusi terhadap keberhasilan implementasi sistem berbasis pengetahuan disajikan. Namun penelitian memiliki kelemahan yakni teknologi baru belum terbukti menjadi obat mujarab untuk semua masalah produktivitas. 


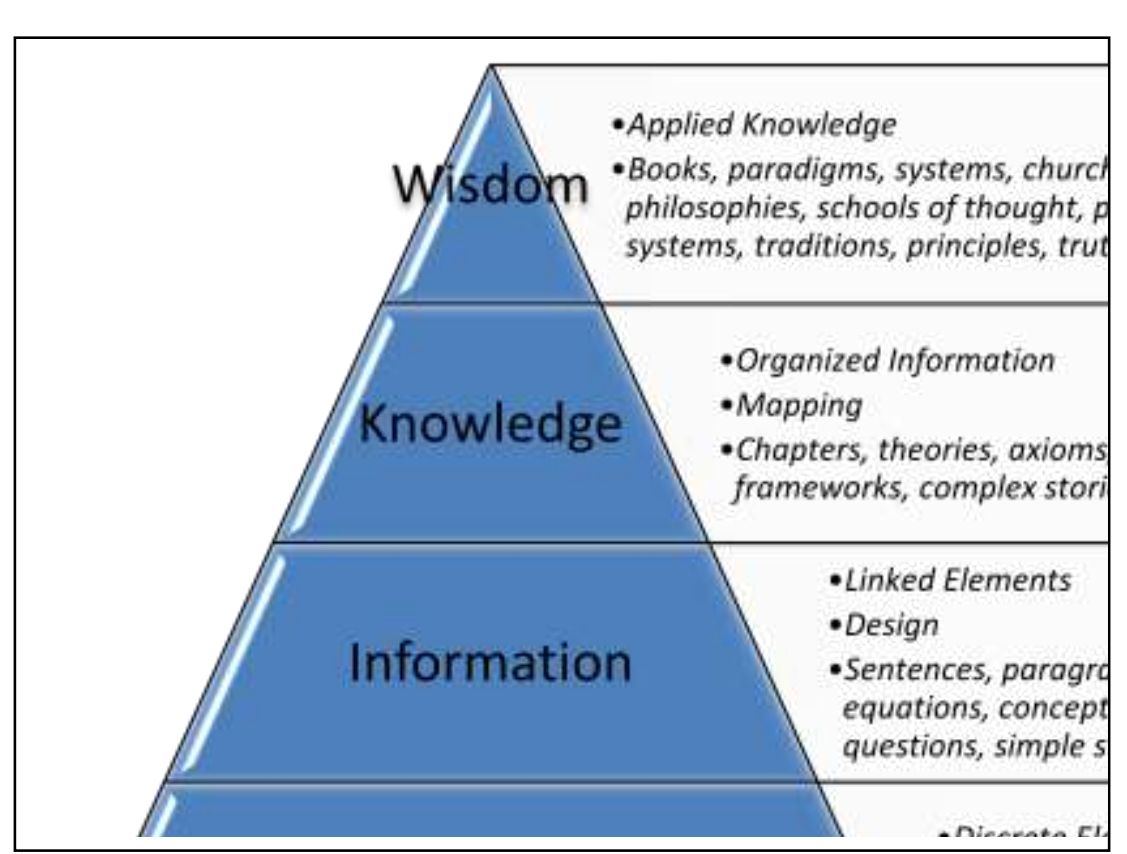

Page : 218-227

Gambar 3. Konsep KMS Piramida Kognitif Manajemen Pengetahuan

Pada penelitian [5] dengan judul Wikis as knowledge management systems issues and challenges, Enam masalah dan tantangan utama yang diidentifikasi dalam penelitian termasuk ada tidak adanya tujuan yang jelas untuk wiki, kegunaan wiki, mengintegrasikan wiki ke dalam praktik kerja yang mapan, masalah sosial, peran manajemen dan budaya organisasi yang mendukung berbagi pengetahuan dan kolaborasi. Tindakan selanjutnya adalah perlu ditangani lebih lanjut untuk membuat model adopsi wiki yang layak.

Pada penelitian [6], Hasilnya menunjukkan bahwa, untuk meminimalkan risiko kegagalan untuk mengadopsi. Sistem KM, suatu perusahaan perlu memilih sistem berdasarkan fungsional, non-fungsional dan transisipersyaratan untuk sistem, serta kekuatan dan kapasitas organisasi. Seharusnya sistem KM tertentudipilih, hanya jika sistem dapat memenuhi semua persyaratan proses KM. Struktur organisasi danfungsionalitas sistem harus dicocokkan sebelum mengadopsi sistem. Hasilnya juga menunjukkan, jika penggunasistem bersifat kolaboratif, memiliki keinginan untuk berbagi pengetahuan yang berharga dan cukup termotivasi untuk digunakan dan diterapkanpengetahuan yang diperoleh dari sistem manajemen pengetahuan seperti wiki dalam operasi sehari-hari, keberhasilantingkat adopsi dan implementasi KMS meningkat. Karena keterbatasan waktu hanya dua kisah kasus suksestelah dievaluasi dan karena ini bukan studi empiris perawatan tambahan harus diambil dalam generalisasitemuan penelitian.

Dan pada penelitian [7], KMS yang telah dibangun pada PT Satria Medikantara Palembang dapat membantu karyawan dalam proses discovery knowledge yaitu mendokumentasikan data pengetahuan agar dapatdisimpan dan dibagi dengan pegawai lainnya, Dengan adanya fitur pencarian (search knowledge), memudahkan pegawai dalam mencari pengetahuan yang mereka inginkan sesuai dengan keyword yang diinputkan, dan KMS ini mampu dijadikan sarana berdiskusi pengetahuan atas permasalahan yang adaantar pegawai sales and customer care dengan memanfaatkan kolom komentar pada pengetahuan yang ada. Dan kedepannya dapat dikembangkan untuk bagian-bagian lainnya di PT Satria Medikantara Palembang. Selain itu, sistem yang dibangun juga diharapkan bisa untuk aplikasi berbasis smartphone. 


\section{Metode Penelitian}

Untuk mengadopsi suatu sistem, Yayasan Pendidikan Telkom harus mengkategorikan kebutuhan sistem menjadi tiga kategori besar yang meliputi persyaratan fungsional, non fungsional dan transisi . Persyaratan fungsional adalah hal-hal yang harus dilakukan oleh solusi, yang dapat digambarkan sebagai tindakan kerja, di mana persyaratan non-fungsional mengacu pada hal-hal yang harus dimiliki oleh suatu solusi, yang seringkali menggambarkan kualitas sistem. Persyaratan ketiga adalah persyaratan transitioanl yang menyarankan langkah-langkah untuk melancarkan implikasi sistem baru. Tabel 1 menunjukkan beberapa persyaratan fungsional, non-fungsional dan transisi untuk sistem Manajemen Pengetahuan. Model untuk Adopsi dan Kegunaan IGracias untuk Knowledge Management Systems dapat dilihat pada Gambar 4.

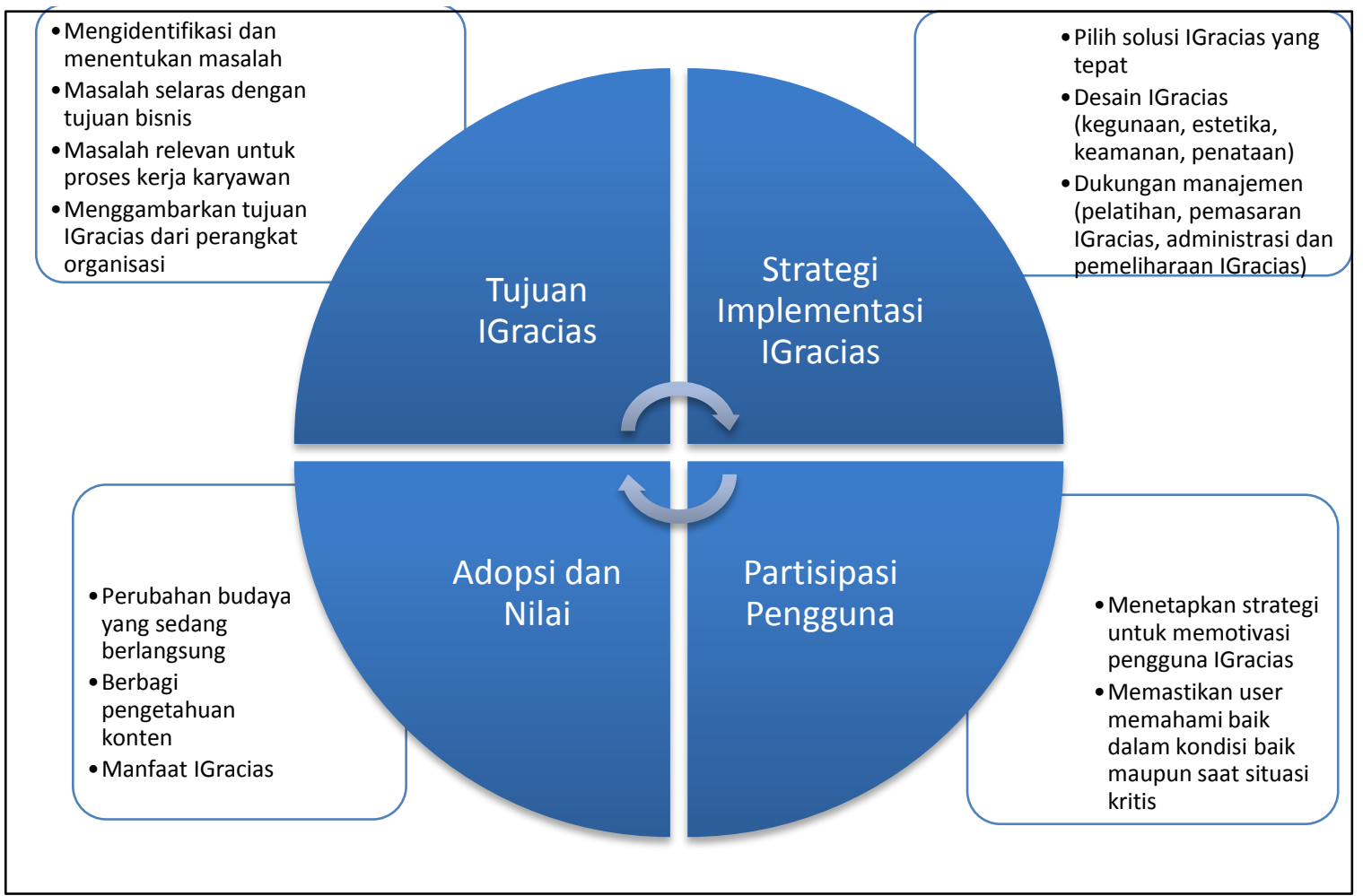

Gambar 4. Model untuk Adopsi dan Kegunaan IGracias untuk Knowledge Management Systems

Tabel 1. Kebutuhan Fungsional, Non-Fungsional dan Transitional dari KMS

\begin{tabular}{|c|c|c|c|c|}
\hline $\begin{array}{l}\text { Knowledge } \\
\text { Management }\end{array}$ & Knowledge Discovery & Knowledge Capture & Knowledge Sharing & Knowledge Application \\
\hline Functional & $\begin{array}{ll}- & \text { Fitur Pencarian Tidak } \\
\text { Terbatas } \\
\text { - } & \text { Mendukung Informasi } \\
& \text { yang sistematis } \\
\text { - } & \text { Alat manajemen atas } \\
\text { pencarian kata kunci }\end{array}$ & $\begin{array}{ll}\text { - } & \text { Arsitektur } \\
\text { manajemen } \\
\text { dokumen yang } \\
\text { tepat. } \\
\text { - } & \text { Pengumpulan } \\
\text { pengetahuan } \\
\text { eksplisit dan tacit } \\
\text { dari pengguna. } \\
\text { Izinkan pengguna } \\
\text { untuk } \\
\text { mengomentari } \\
\text { konten untuk }\end{array}$ & $\begin{array}{ll}\text { Berbagi } \\
\text { pengetahuan di } \\
\text { seluruh lokasi } \\
\text { geografis. } \\
\text { - } \quad \text { Izinkan } \\
\text { komunikasi } \\
\text { Kolaborasi } \\
\text { Mendukung } \\
\text { berbagi konten } \\
\text { dalam berbagai } \\
\text { format (yaitu teks, } \\
\text { gambar, PDF, }\end{array}$ & $\begin{array}{ll}\text { - } & \text { Harus mengizinkan } \\
\text { untuk melakukan } \\
\text { pekerjaan } \\
\text { administratif } \\
\text { - } \quad \text { Mudah digunakan } \\
\text { Harus selaras } \\
\text { dengan struktur } \\
\text { organisasi dan } \\
\text { proses bisnis }\end{array}$ \\
\hline
\end{tabular}


Jurnal KomtekInfo, Vol.7 No.3 Tahun 2020

e-ISSN : 2502-8758 || p-ISSN : $\underline{2356-0010}$

DOI : $\underline{10.35134 / \text { komtekinfo.v7i3 }}$

Page : 218-227

\begin{tabular}{|c|c|c|c|c|c|c|}
\hline & & & & $\begin{array}{l}\text { meningkatkan } \\
\text { akurasi konten }\end{array}$ & $\begin{array}{l}\text { video, dll.) } \\
\text { Memungkinkan } \\
\text { berbagi } \\
\text { pengetahuan dari } \\
\text { orang ke orang } \\
\text { tanpa perlu banyak } \\
\text { email. }\end{array}$ & \\
\hline Non Functional & & $\begin{array}{l}\text { Mendukung diskusi, } \\
\text { membuat dan } \\
\text { menganalisis konten } \\
\text { Memberikan peluang } \\
\text { dalam menciptakan } \\
\text { pengetahuan baru dengan } \\
\text { memanfaatkan kontribusi } \\
\text { kecil dari komunitas luas }\end{array}$ & & $\begin{array}{l}\text { Memiliki server } \\
\text { perangkat lunak } \\
\text { dan server } \\
\text { database untuk } \\
\text { menangkap dan } \\
\text { menyimpan } \\
\text { pengetahuan } \\
\text { dengan benar. } \\
\text { Dapat } \\
\text { menggunakan } \\
\text { server virtual } \\
\text { sebagai } \\
\text { penyimpanan. } \\
\text { Mudah untuk } \\
\text { berkontribusi, } \\
\text { memodifikasi dan } \\
\text { memperbarui } \\
\text { konten } \\
\text { Mudah untuk } \\
\text { menangkap } \\
\text { informasi yang } \\
\text { relevan dari } \\
\text { database }\end{array}$ & 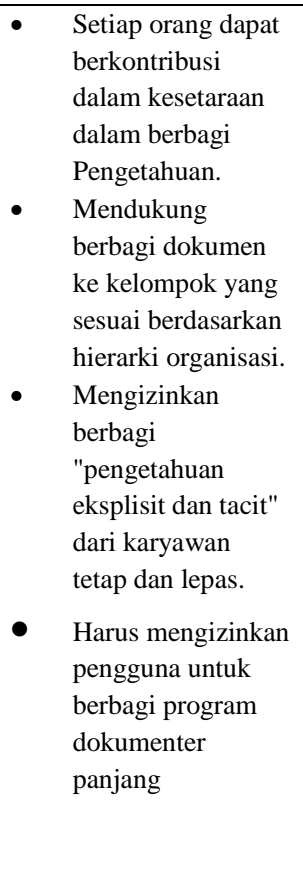 & $\begin{array}{ll}\text { - } & \text { Hemat Biaya } \\
\text { - } & \text { Biaya perawatan } \\
\text { yang rendah } \\
\text { - Sistem tidak } \\
\text { memerlukan } \\
\text { pemeliharaan } \\
\text { ekstensif oleh tim } \\
\text { TI. }\end{array}$ \\
\hline Transitional & & $\begin{array}{l}\text { Dapat diakses dari } \\
\text { perangkat seluler }\end{array}$ & & $\begin{array}{l}\text { Mampu melacak } \\
\text { alur kerja. } \\
\text { Dapat menangkap } \\
\text { pengetahuan dari } \\
\text { pekerja } \\
\text { pengetahuan } \\
\text { secara real time. } \\
\text { Memungkinkan } \\
\text { pengguna untuk } \\
\text { berbagi ide. }\end{array}$ & $\begin{array}{l}\text { Diperlukan untuk } \\
\text { mempertahankan } \\
\text { langkah yang } \\
\text { berbeda untuk } \\
\text { memasukkan } \\
\text { berbagi informasi } \\
\text { atau pengetahuan } \\
\text { dalam database } \\
\text { (yaitu proses } \\
\text { modifikasi konten, } \\
\text { sebelum } \\
\text { mengunggah ke } \\
\text { database) }\end{array}$ & $\begin{array}{ll}- & \text { Desain Interface } \\
& \text { Pengguna yang } \\
\text { Mudah } \\
\text { - } & \text { Proses otentikasi } \\
& \text { terintegrasi di } \\
\text { seluruh perangkat } & \text { lunak jaringan } \\
\text { Telkom Campus. } \\
\text { - } & \text { Sistem harus } \\
\text { terpusat dan bekerja } \\
\text { dengan lancar }\end{array}$ \\
\hline
\end{tabular}

\section{Evaluasi Solusi Sistem dalam KMS (Knowledge Management System)}

\section{Analisis sistem berdasarkan proses KMS}

Sistem Adopsi IGracias pada penelitian ini menerapkan konsep sistem KMS berisi empat proses KM utama yang didukung oleh tujuh sub-proses. Proses KMS utama adalah knowledge discovery, knowledge capture, knowledge staring dan knowledge application yang didukung oleh subproses seperti kombinasi, sosialisasi, eksternalisasi, internalisasi, pertukaran, arahan dan rutinitas. Hal ini bisa dilihat pada Gambar 5. 


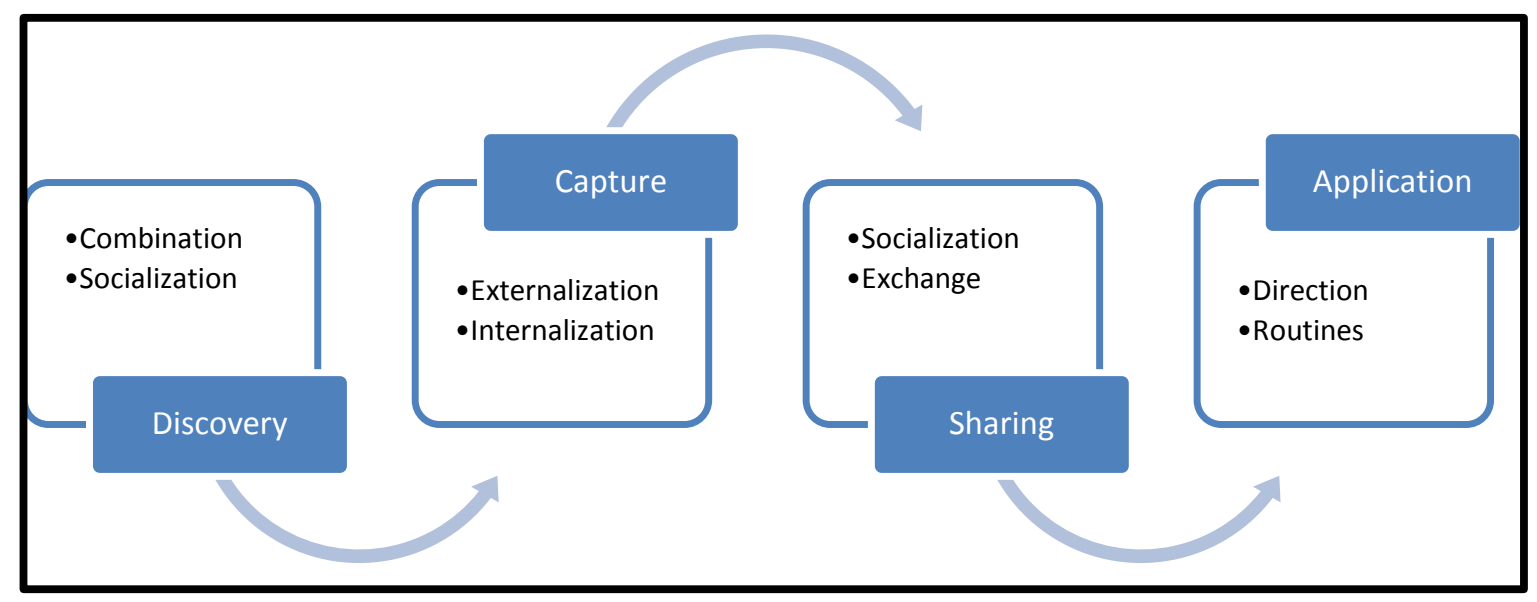

Gambar 5. Knowledge Management System Process

\section{Knowledge Discovery}

Perkembangan pengetahuan tacit atau explicit baru dari data dan informasi atau dari sintesis pengetahuan sebelumnya. Hal itu bisa diperoleh dari proses combination (penemuan pengetahuan eksplisit baru) dan socialization (penemuan pengetahuan tacit baru).

\section{Knowledge Capturing}

Proses mengambil pengetahuan explicit atau tacit yang ada di dalam orang, artefak, entitas organisasi. Hal itu bisa diperoleh dari proses Externalization (menangkap pengetahuan dari tacit ke explicit) dan Internalization (menangkap pengetahuan dari explicit ke tacit)

\section{Knowledge Sharing}

Proses di mana pengetahuan explicit atau tacit dikomunikasikan kepada individu lain. Hal itu bisa diperoleh dari proses Socialization (memfasilitasi berbagi tacit knowledge dalam kasus-kasus di mana tacit knowledge baru sedang dibuat serta saat tacit knowledge baru tidak dibuat) dan proses Exchange (berbeda dengan sosialisasi, berfokus pada berbagi pengetahuan eksplisit. Ini digunakan untuk mengkomunikasikan atau mentransfer pengetahuan eksplisit antara individu, kelompok, dan organisasi).

\section{Knowledge Applying}

Proses di mana individu memanfaatkan pengetahuan yang dimiliki oleh individu lain tanpa benar-benar memperoleh, atau mempelajari, pengetahuan itu. Hal itu bisa diperoleh dari proses Direction dan Routines.

Dari Proses KMS utama yakni knowledge discovery, knowledge capture, knowledge staring dan knowledge application pada proses adopsi IGracias maka akan menimbulkan konsep Instrumen Penelitian IGracias dengan adopsi Knowledge Management System Research seperti pada Tabel 2.

Tabel 2. Instrumen Penelitian IGracias Knowledge Management System Research

\begin{tabular}{lll}
\hline \multicolumn{1}{c}{ Variabel } & \multicolumn{1}{c}{ Pertanyaan } & \multicolumn{1}{c}{ Sumber } \\
\hline $\begin{array}{l}\text { KM \& KMS } \\
\text { Effectiveness }\end{array}$ & $\begin{array}{l}\text { Terdapat dukungan kebijakan Pimpinan untuk mengimplementasikan } \\
\text { praktik Knowledge Management System IGracias. }\end{array}$ & $\begin{array}{l}\text { Bechina \& Ndelea } \\
(2009)\end{array}$ \\
& $\begin{array}{l}\text { Terdapat Workshop untuk praktik implementasi Knowledge Management } \\
\text { System IGracias. }\end{array}$ & \\
& $\begin{array}{l}\text { Manajemen menjamin adanya penyelarasan tujuan bisnis dengan } \\
\text { teknologi IGracias. }\end{array}$
\end{tabular}


Manajemen menjamin adanya kolaborasi dan budaya adaptif dalam implementasi IGracias.

Manajemen menjamin adanya keterbukaan informasi dan komunikasi secara kontinu dalam proses implementasi IGracias.

Knowledge Discovery System
Sistem mendukung pencarian informasi dengan keyword tertentu secara sistematis dan menyeluruh pada IGracias.

S.Biswas (2017.)

Sistem mendukung pengguna untuk berdiskusi, membuat dan menganalisis konten, sehingga dapat memberikan kontribusi yang besar bagi pengguna IGracias lainnya.

Sistem memungkinkan untuk diakses pengguna IGracias dari berbagai jenis perangkat, baik komputer, laptop, mobile dan lain sebagainya.

Sistem menyediakan video singkat kepada pengguna IGracias saat memasuki fitur tersebut pertama kalinya.

Knowledge Sistem mengizinkan pengguna untuk mengomentari konten dengan tujuan Capture System

meningkatkan akurasi dari fungsionalitas IGracias.
Sistem memiliki dokumen yang tepat dalam pengelolaan Arsitektur IGracias.

Terdapat server dan database server yang tepat untuk menangkap dan menyimpan informasi di IGracias.

Sistem memberikan kemudahan untuk menangkap informasi yang relevan dari database IGracias.

Sistem memungkinkan pengguna untuk berbagi ide dan pengetahuan secara real time di IGracias.

Sistem mampu menangkap alur kerja IGracias.

Tabel 3. Instrumen Penelitian IGracias Knowledge Management System Research

Variabel Pertanyaan Sumber

Knowledge Terdapat kebijakan untuk mempelajari keahlian atau pengetahuan baru dan Sharing System membaginya dengan pengguna lainnya.

Terdapat kebijakan harus pro aktif memberikan saran dan masukan atas kekurangan dan eror pada fitur atau fungsional praktik IGracias terhadap pengembang.

Terdapat praktik workshop pelatihan fitur, fungsionalitas dan dokumen manual pengoperasian IGracias.

Terdapat laman untuk berbagi manual fitur yang dapat diakses dengan mudah oleh user IGracias.

\section{Knowledge \\ Application}

System
Terdapat praktik yang mudah untuk menggunakan dan memanfaatkan fitur IGracias.

Terdapat praktik fitur menu IGracias yang sesuai dengan struktur organisasi dan proses bisnis.

Terdapat praktik antar muka fitur yang mudah dipahami oleh semua pengguna. 
Terdapat kemudahan untuk mengakses IGracias dari segala jenis penyedia layanan jaringan.

\begin{tabular}{|c|c|c|}
\hline \multirow[t]{4}{*}{ System Quality } & Sistem IGracias menyelaraskan antara tujuan bisnis dengan teknologi. & Bechina \& Ndelea (2009) \\
\hline & Sistem memiliki dan memberikan manfaat potensial yang jelas. & \\
\hline & $\begin{array}{l}\text { Sistem IGracias menjamin penyelarasan sistem untuk dapat diakses dari } \\
\text { berbagai bentuk teknologi. }\end{array}$ & \\
\hline & $\begin{array}{l}\text { Sistem IGracias mendukung budaya adaptif terhadap perubahan organisasi } \\
\text { yang sangat dinamis. }\end{array}$ & \\
\hline \multirow[t]{4}{*}{ Information Use } & $\begin{array}{l}\text { Terdapat praktik komunikasi yang baik antar tingkatan pengguna di IGracias, } \\
\text { terutama saat transfer pengetahuan fitur dan perubahannya. }\end{array}$ & Bechina \& Ndelea (2009) \\
\hline & $\begin{array}{l}\text { Terdapat praktik pelatihan terhadap fitur baru IGracias, baik melalui sistem } \\
\text { aplikasi atau manajemen pengelola. }\end{array}$ & \\
\hline & $\begin{array}{l}\text { Terdapat praktik Transfer Informasi IGracias atas Perubahan struktural } \\
\text { manajemen Organisasi. }\end{array}$ & \\
\hline & $\begin{array}{l}\text { Terdapat forum pembahasan atas perubahan kebijakan pimpinan atas } \\
\text { penggunaan atau implementasi IGracias. }\end{array}$ & \\
\hline
\end{tabular}

Tabel 4. Instrumen Penelitian IGracias Knowledge Management System Research

\begin{tabular}{|c|c|c|}
\hline Variabel & Pertanyaan & Sumber \\
\hline $\begin{array}{l}\text { Information } \\
\text { Quality }\end{array}$ & $\begin{array}{l}\text { Standar informasi yang disajikan di IGracias telah selaras dengan } \\
\text { Strategi Bisnis organisasi. } \\
\text { IGracias memiliki fitur yang mengkolaborasikan berbagai informasi } \\
\text { sehingga mudah untuk dibaca. Seperti: dashboard system. } \\
\text { Informasi di IGracias mampu meningkatkan motivasi pengguna untuk } \\
\text { memperoleh atau mempertahankan reward. } \\
\text { Informasi di IGracias mampu membuat pengguna menikmati dan } \\
\text { merasa mudah mengaplikasikannya. }\end{array}$ & Bechina \& Ndelea (2009) \\
\hline \multirow[t]{2}{*}{ User Satisfaction } & $\begin{array}{l}\text { IGracias mudah digunakan dan banyak manfaat yang dapat diperoleh } \\
\text { pengguna. }\end{array}$ & Bechina \& Ndelea (2009) \\
\hline & $\begin{array}{l}\text { IGracias memberikan fitur yang ramah dan mudah dipelajari pengguna. } \\
\text { IGracias memberikan reward kepada pengguna yang menikmati sistem } \\
\text { dengan baik. } \\
\text { Terdapat praktik pemberian reward kepada pengguna yang memiliki } \\
\text { skill baik dalam penggunaan IGracias. } \\
\text { Terdapat praktik Learning and Training IGracias secara berjenjang } \\
\text { sesuai poin capaian pengguna. Contoh: adanya fitur pengumpulan poin } \\
\text { setelah menguasai fitur-fitur tertentu. } \\
\text { IGracias memberikan kemudahan pengguna mengakses reward yang } \\
\text { dicapai selama bekerja dengan sistem. }\end{array}$ & \\
\hline
\end{tabular}

\section{Kesimpulan dan Saran}

KMS adalah teknologi yang relatif baru. Sistem KMS harus dirancang sedemikian rupa sehingga dapat dicocokkan dengan struktur organisasi. Jika semua prosedur sistem diikuti dengan ketat maka tingkat keberhasilan sistem KMS baru meningkat secara signifikan. Keberhasilan sebuah KMS bergantung pada bagaimana penggunaanya menggunakan sistem tersebut. Jika penggunaan, dalam hal ini karyawan organisasi lebih kolaboratif, berbagi pengetahuan yang berharga dengan rekan kerja mereka dan orang penting lainnya dalam organisasi, maka tingkat keberhasilan KMS meningkat. Selain itu jika setiap anggota organisasi cukup termotivasi untuk menggunakan dan mengaplikasikan ilmu yang diperoleh dari KMS, maka organisasi tersebut dapat menjadi organisasi yang efektif dalam menerapkan sistem manajemen pengetahuan, yang dapat memberikan keunggulan komparatif atas pesaingnya dalam jangka panjang. Studi ini telah menunjukkan beberapa bukti tentang bagaimana sistem manajemen pengetahuan seperti sistem IGracias harus diadopsi dan diimplementasikan. Penelitian selanjutnya diharapkan untuk melakukan penelitian dengan 
memeriksa apakah strategi penerapan KMS ini, dapat membawa kesuksesan bagi lembaga pendidikan tinggi yang ada pada naungan Yayasan Pendidikan Tinggi dengan menggunakan pemeriksaan metrics performance.

\section{DAFTAR PUSTAKA}

[1] L. A. Abdillah et al., "Computer science students simulation in capturing tacit knowledge by using NGT for reducing traffic jam," International Journal of Engineering and Technology(UAE), vol. 7, pp. 1463-1467, 11 July 2018.

[2] L. A. Abdillah, "Managing information and knowledge sharing cultures in higher educations institutions," in The 11th International Research Conference on Quality, Innovation, and Knowledge Management (QIK2014), The Trans Luxury Hotel, Bandung, Indonesia, 2014.

[3] B. A. Alyoubi, "Decision support system and knowledge-based strategic management," presented at the International Conference on Communication, Management and Information Technology (ICCMIT2015), 2015.

[4] Arntzen, Aurilla A. and M. N. Ndlela. "Success Factors in Implementing Knowledge Based Systems." (2009).

[5] S. Kiniti and C. Standing, "Wikis as knowledge management systems: issues and challenges," Journal of Systems and Information Technology, vol. 15, no. 2, pp. 189-201, Apr. 2013.

[6] Shaon Biswas, "Adoption of Knowledge Management Systems: A Study on How Wiki Systems Should Be Adopted by Minimizing the Risk of Failure", Journal of Systems and Information Technology Vol. 15 No. 2, 2013 pp. 189-201 Emerald Group Publishing Limited 1328-7265, August 2017.

[7] Yandi Pranata, Leon Andretti Abdillah, Siti Sa'uda, "Penerapan Knowledge Management System Sales and Customer Care pada PT Satria Medikantara Palembang", Bina Darma Conference on Computer Science Fakultas Ilmu Komputer Universitas Bina Darma, Oct 2019.

[8] D. Rahmawati, M. Ainul Yaqin, and R. Sarno, "Fraud detection on event logs of goods and services procurement business process using Heuristics Miner algorithm," 2016 International Conference on Information \& Communication Technology and Systems (ICTS), 2016.

[9] D. Rahmawati, R. Sarno, C. Fatichah, and D. Sunaryono, "Fraud detection on event log of bank financial credit business process using Hidden Markov Model algorithm," 2017 3rd International Conference on Science in Information Technology (ICSITech), Oct. 2017.

[10] T Kristanto, M Sholik, D Rahmawati, M Nasrullah, Analisis Manajemen Keamanan Informasi Menggunakan Standard ISO 27001: 2005 Pada Staff IT Support Di Instansi XYZ, JISA (Jurnal Informatika dan Sains) Vol 2. No. 2, 2019.

[11] N. P. Istyanto and M. Nasrulloh, "Disruptif Teknologi E-Government terhadap Pelayanan Publik Tradisional Masyarakat Surabaya di Era Industri 4.0," INTEGER: Journal of Information Technology, vol. 4, no. 2, Oct. 2019.

[12] D. Rahmawati and R. Sarno, "Anomaly detection using control flow pattern and fuzzy regression in port container handling," Journal of King Saud University - Computer and Information Sciences, Jan. 2019. 